\title{
Plant evaluations for living roofs in Auckland, New Zealand
}

\author{
Emma Bodley', Robyn Simcock ${ }^{2}$ \& Rebecca Stanley ${ }^{3}$
}

\begin{abstract}
Living roofs have environmental benefits, particularly in an urban setting, such as slowing water runoff, reducing runoff volume, improving air quality and promoting cooling evapotranspiration. This report presents the most successful native and exotic plants for living roofs in Auckland based on ten years of data collected in trials at Auckland Botanic Gardens. Twenty-nine species suitable for thin green roofs in Auckland are identified including several species native to New Zealand such as Coprosma acerosa, Leptospermum scoparium (prostrate forms) and Carex pumila, as well as exotic species such as Aloe humilis, Neoregelia and Tulbaghia violacea. Some well-known living roof plants from the northern hemisphere do not perform well, and the contrasts between northern hemisphere habitats and species choice, and those in the southern hemisphere are discussed. Lists of plants that have performed well and those that have performed less well are provided.
\end{abstract}

\section{Introduction}

An extensive living roof is constructed using load-bearing structures with a thin layer (50-200 mm) of substrate (growing medium) that supports a range of plants. Roofs, especially those with less than 200 to $300 \mathrm{~mm}$ of substrate, are very tough environments for plants for several reasons:

- There is often no shade on a living roof, and this combined with elevation means it can be windier and more exposed than at ground level. If this is the case, there is increased evapotranspiration, especially when combined with low humidity (Voyde et al., 2010).

- The substrate is often thin to limit roof weight and rapidly draining to prevent water ponding, which also adds weight. Roofs with a slope of more than 5 degrees drain even more quickly. Plants in green roof systems therefore have limited root volume and are often subjected to many more cycles of drought each summer than plants in the ground.

- Because they are thin, substrates and the roots in them experience much greater temperature extremes, both hot and cold. Concrete roofs without insulation are particularly vulnerable to high root temperatures compared to a roof surrounded by green space, as concrete stores heat.

- The substrate must have low organic matter. This is required under

\footnotetext{
${ }^{1}$ Emma Bodley is Botanical Records and Conservation Specialist at Auckland Botanic Gardens. Address: 102 Hill Road, Manurewa, Auckland, New Zealand.

Email: emma.bodley@aucklandcouncil.govt.nz

${ }^{2}$ Robyn Simcock is an Ecologist/Soil Scientist, Manaaki Whenua Landcare Research.

Address: Private Bag 92170, Auckland Mail Centre, Auckland, New Zealand.

${ }^{3}$ Rebecca Stanley is Principal Advisor, Conservation Partnerships, at Auckland Council.

Address: 135 Albert Street, Auckland, New Zealand.
} 
international standards to reduce fire risk, but a low organic matter content also minimises substrate shrinkage over time. However, this can reduce moisture storage and nitrogen availability, which is an issue because fertilisers are sparsely used where stormwater runoff enters surface waters.

Every roof will have its own combination of these issues, forming its own 'microclimate'. Multiple microclimates potentially exist within a single roof. The microclimate depends on the depth of the substrate, the aspect of the roof, its slope/drainage, the surroundings, local weather patterns and the type of substrate used (Roehr \& Fassman-Beck, 2015). For example, some roofs will be more exposed than others and therefore drier. Some will have deeper substrate than others which is of great benefit to the plants but makes the roof much heavier and is therefore often more expensive in terms of building cost. Conditions vary across a roof, for example corners and ridgelines are particularly exposed to wind turbulence whereas plants near air conditioning units may be less stressed if they receive water runoff or shade, or more stressed if they are dried by the fans.

For a living roof to function as a stormwater device (i.e. reducing stormwater volumes discharged and slowing flows into stormwater systems) more than 60 per cent of the roof should be covered in plants (Cunningham et al., 2017). The leaves and stems of plants physically protect the substrate from wind erosion, and plant roots hold the substrate of the living roof against water erosion as well as taking up water. Low vegetation cover can therefore allow erosion of substrate. High plant cover also helps exclude weeds or other undesirable plants. Some native trees such as Metrosideros excelsa (pōhutukawa), Kunzea robusta (kānuka), Coprosma robusta (karamu) and Cordyline australis (ti kōuka, cabbage tree) which frequently seed onto the living roofs in Auckland and Dunedin are undesirable as they may blow over when they get too tall or develop roots into drainage layers (especially pōhutukawa). Undesirable plants on the green roof may be referred to as 'weeds' or 'weedy' for this reason and need to be removed during maintenance.

In the northern hemisphere, the first modern, thin living roofs (in 1980s Germany) supported Sedum, other hardy succulents, bulbs (notably Allium schoenoprasum) and grasses (Festuca, Bromus and Poa) (Köhler, 2006; Köhler \& Poll, 2010); in Normandy, Sempervivium (house leeks) and Iris were planted on the ridges of thatch roofs. Our plant selections have been inspired by the plant types and species based on the large body of research into living roofs over long periods of time in the northern hemisphere (Dunnett \& Kingsbury, 2008; Wethermann, 2007). Interestingly, the very first extensive roofs were turf or sod roofs in Scandinavia and Ireland, although other methods for living roof plantings are used now, including in New Zealand. Turf grasses established into soil are also used to hide reservoirs on Auckland volcanic cones (such as Ohinerau/Mt Hobson, Mangawhau/Mt Eden, Maungarei/Mt Wellington and Pukekawa/ Auckland Domain).

Sedum and succulents, such as iceplants (in the family Aizoaceae, including Lampranthus and Mesembryanthemum), remain the most widely used plants for thin, lightweight living roofs across Europe and North America. They are cost-effective to produce from seed or cuttings, diverse (over 600 species) and extremely hardy, tolerating 
drought, heat and wind (Agra et al., 2021; Guo et al., 2021; Snodgrass \& Snodgrass, 2006).

Over the last 15 years the plant choices for roofs have expanded as more research is done and the total area of living roofs has rapidly increased, leading to the provision of detailed guidance for North America and Europe (Dunnet \& Kingsbury, 2008; Dvorak, 2021; Getter \& Rowe, 2008; Snodgrass \& Snodgrass, 2006; Snodgrass \& Mclntyre, 2010; Sutton, 2015). Roofs with a substrate depth of over $50 \mathrm{~cm}$ can support very similar plants to gardens on the ground, albeit with shorter trees, especially if supplemented with irrigation and pruned or supported to prevent windthrow. The trade-off is that these roofs need very strong structural support and are therefore usually more expensive to construct. Some living roofs may even attempt to mimic wild natural habitats such as rare limestone grassland habitats in the UK (Dunnet \& Kingsbury, 2008; Lundholm, 2006) and may in the future contribute to the restoration of native ecosystems in urban settings and/or ex situ plant conservation. Living roofs are even becoming accessible for home gardeners with the availability of popular DIY guides on the construction of roofs and planting at home (Gedge \& Little, 2008; Maguire \& Woods, 2017).

\section{Selecting the ideal living roof plant in New Zealand}

Most books and guides on living roofs are written about and for the northern hemisphere. Very few consider green roofs in the southern hemisphere, particularly in Australia and New Zealand (Hopkins \& Goodwin, 2011; Irga et al., 2017). Plant lists from these guides are not always relevant for New Zealand conditions; they are unlikely to include native New
Zealand plants, as 80 per cent are endemic, and many plants on lists are invasive or likely to become so in some New Zealand ecosystems, including certain Sedum and Crassula species (Howell, 2008; Weedbusters, 2016). The native New Zealand flora is now outnumbered by naturalised exotic plants (Brandt et al., 2021). The native flora has few annuals, and few herbaceous plants suitable for open sites, apart from those associated with wetlands. Forest trees are the most common native plants to self-seed in any garden setting, including roofs. When making our plant selection in New Zealand, the following points are key considerations based on our experience:

- $\quad$ evergreen and perennial (although summer-dormant bulbs and springflowering annuals can be very effective 'accents')

- $\quad$ ground covers with self-anchoring stems (Coprosma) and permeable forms (tussocks)

- drought tolerant (only irrigation in exceptional droughts)

- tolerant of low-nitrogen conditions

- $\quad$ short-statured, with non-invasive roots that have low potential to damage membranes or drainage systems

- tolerant of wind, full sun and warm root systems, if the roof is exposed to full or afternoon sun, especially if sloping towards the north-west to west (afternoon sun)

- non-weedy and won't establish in nearby natural ecosystems

We have reviewed some of the rich literature on the plant types (for example families and growth habits) that are successful on living roofs in the northern hemisphere and have attempted to select native plants that mimic 
these. Plant selection is based on the 'habitat template approach' by looking at species from ground-level habitats that have similar stresses of shallow root zone, high exposure and drought stress. Alternatively it may be carried out using a 'trait-based approach', selecting species with morphological traits such as succulence or physiological traits such as low water requirements or the ability to quickly down-regulate water use when drought-stressed (Schrieke \& Farrell, 2021).

However, New Zealand has few habitats analogous to those that inform plant selection overseas, and few families with any similar species. The closest ecosystems to meadows are wetlands, saltmarshes and alpine areas. Few of the native plants in these habitats are likely to survive on a living roof in Auckland. The other closest natural ecosystems to roofs are rock outcrops (Lundholm, 2006; Schrieke \& Farrell, 2021) and epiphytes.

The New Zealand naturalised exotic flora now outnumbers the New Zealand native flora (Brandt et al., 2021). Most self-seeded plants in urban areas and gardens are non-native plants, of which some are environmental weeds. We cannot rely on herbaceous native flora colonising a living roof as there are not many native ecosystems that are analogous to a living roof.

It would be simple if New Zealand horticulturists and landscapers could use recommended living roof plant lists from Europe and North America. While plant traits/ characteristics and plant growth forms can usefully inform plant selection for roofs in New Zealand, such as coastal adapted plants (Nagase \& Tashiro-Ishii, 2018), many of the northern hemisphere roof plants are not available in New Zealand. New plants cannot be imported into New Zealand without permits and this is cost prohibitive for all but those who can reliably make large economic returns. Further, some species may not grow in New Zealand even if present, and others are or could become environmental weeds. The spread of plants from gardens, such as on living roofs, should not further threaten our native ecosystems. Thus, promoting native and non-weedy plants for living roofs is one measure that can contribute to the conservation of the New Zealand flora (and the associated insects that depend on them) in urban environments.

Some New Zealand native plants can grow very well on living roofs. Most are found naturally in coastal habitats. Such habitats include environmental conditions similar to a living roof, i.e. limited soil and shade, high winds (so can be hot and dry) and drought stress accentuated by salt-laden wind/spray. Living roofs in public settings such as botanic gardens offer an opportunity for the public to see and learn more about this technology that has a longer history in the northern hemisphere. Native plant living roofs can be visited at Auckland Botanic Gardens (ABG) on the Potter Children's Garden toilet block (Avery \& Davies, 2019), Auckland Zoo on the wetland bird aviary and wood-shingled shelters, and the Auckland Domain non-native roof on the toilet block. They are increasingly seen on commercial buildings such as the Auckland International Airport offices on Leonard Isset Drive. Other living roof case studies around New Zealand are highlighted in Hopkins \& Goodwin (2011).

At $A B G$, our gardening philosophy is to ensure all the plants grown are healthy and self-sustaining in Auckland conditions without the use of agri-chemical sprays. We apply this same principle to our living roof plant selection. We are trialling plants to find those best suited to Auckland conditions and 
the microclimates of each roof in a native species and an exotic species living roof trial. In this paper, we describe both native and exotic trials on two living roofs at $A B G$ and identify species that perform well in Auckland conditions.

\section{Methods}

Two living roofs were constructed in the Potter Children's Garden in 2010 (Avery \& Davies, 2019). A 3-degree sloped roof measuring $12.9 \mathrm{~m}^{2}$ over the Children's Garden entrance (Fig. 1) was designed for maximum visual impact within the height and volume constraints imposed by a substrate $100 \mathrm{~mm}$ deep. A $22.9 \mathrm{~m}^{2}$ sloping roof was designed to blend into the surrounding green native plantings (Fig. 2). The design and construction of these living roofs is detailed in Fassman et al. (2010a), in particular the development and verification of the substrate (80 per cent $\mathrm{v} / \mathrm{v}$ pumice, 5 per cent zeolite, 10 per cent bark fines and 5 per cent coir) which used a single pumice and composted bark supplier, allowing blending at one site which was consistent with the recommended substrate blend in TR2010/17 17/2010 (Fassman et al., 2010a \& b).

Both living roofs were watered regularly during the first two summers to encourage establishment. They were fertilised in late 2012, and two fertiliser applications were trialled including a light dressing of generalpurpose fertiliser at a rate of $30 \mathrm{~g} / \mathrm{m}^{2}$ and sheep pellets at $120 \mathrm{~g} / \mathrm{m}^{2}$ (3 per cent $\left.\mathrm{N}\right)^{2}$. Application of organic fertiliser (sheep pellets) to only one side of the roof enabled us to observe the positive effect on plant health.

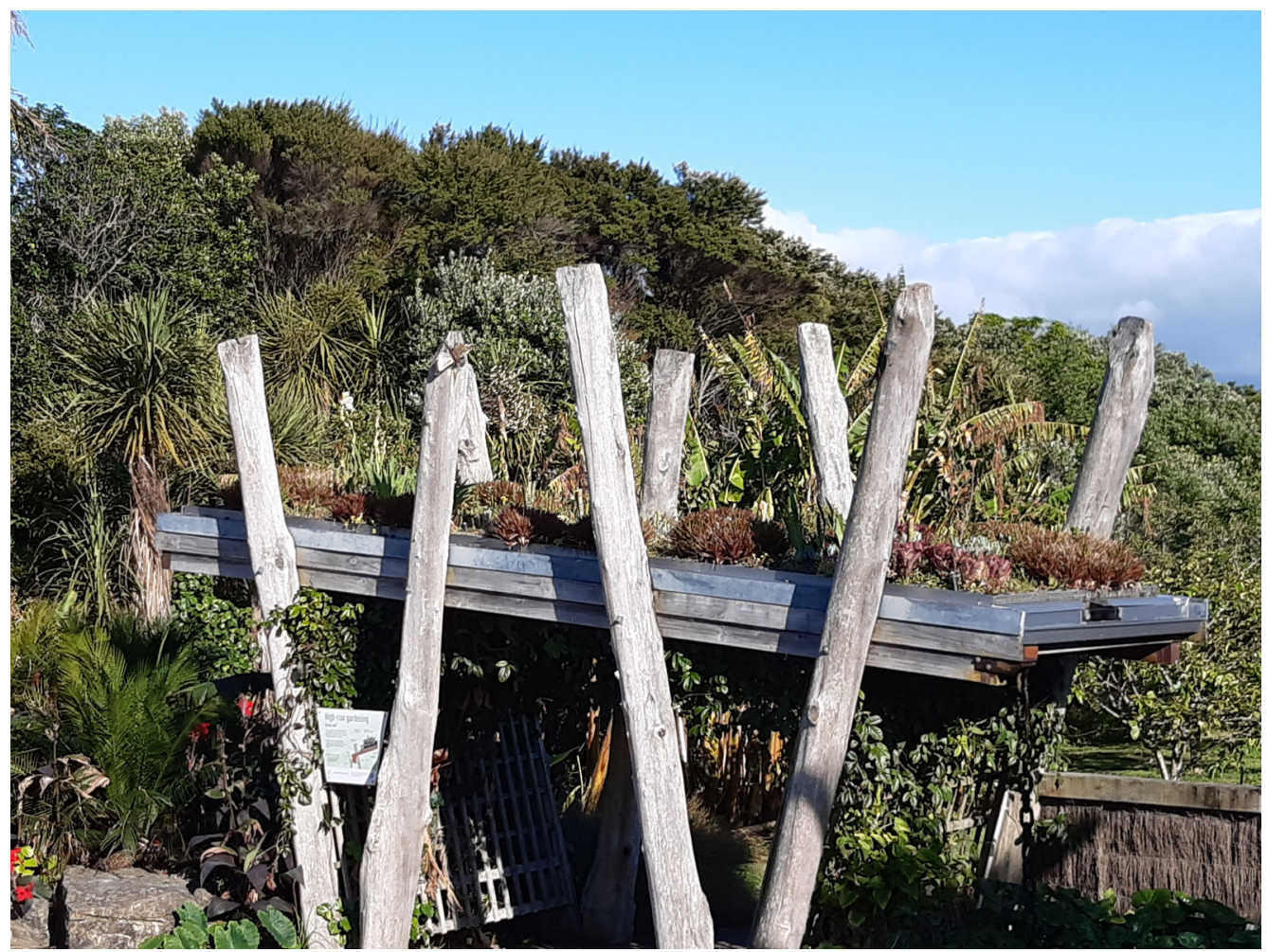

Fig. 1 Exotic plant living roof at the entrance to the Children's Garden at Auckland Botanic Gardens, November 2020. Photo: Auckland Botanic Gardens. 


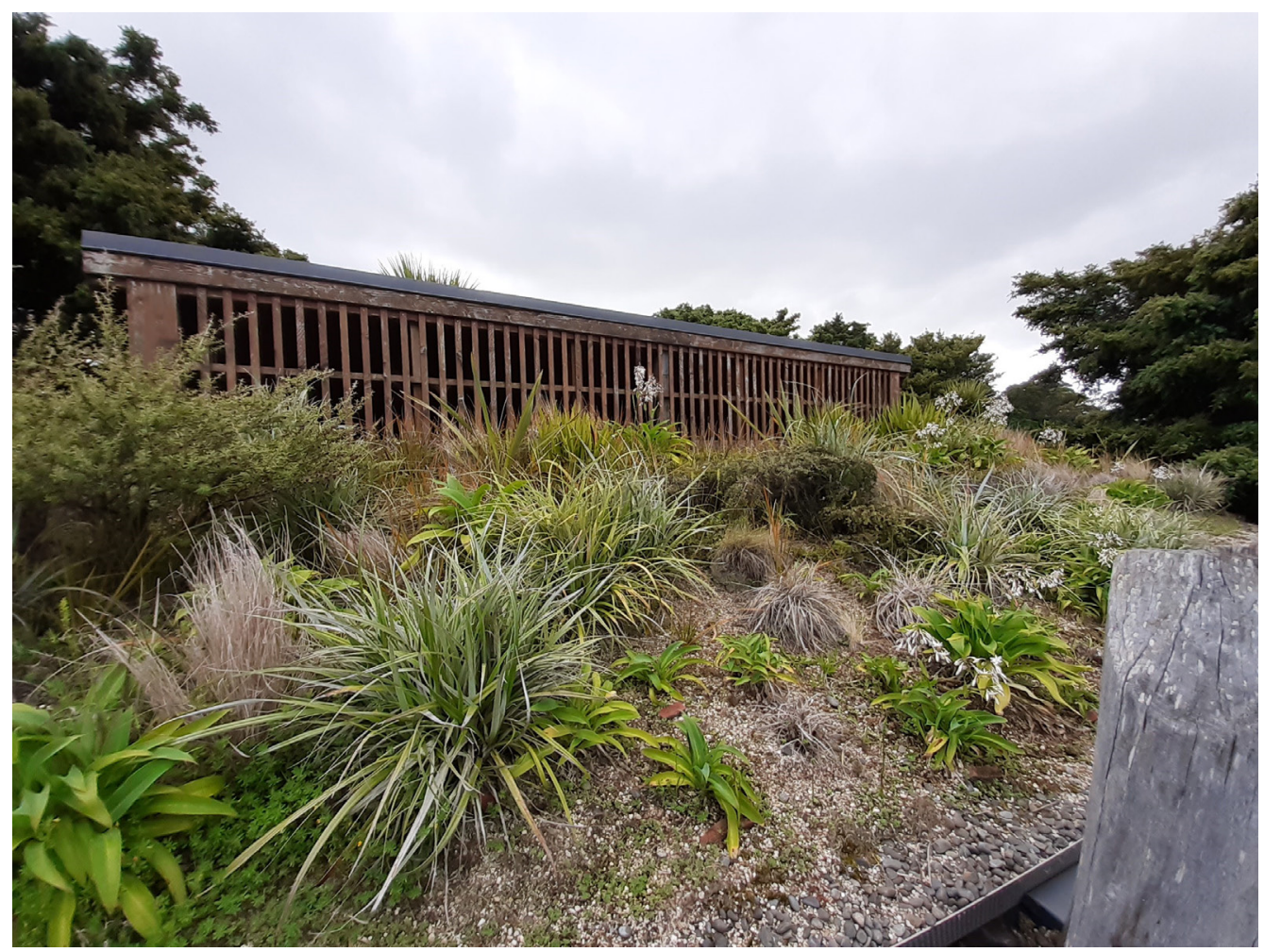

Fig. 2 Native plant living roof on the Children's Garden toilet block at Auckland Botanic Gardens, November 2020. Photo: Auckland Botanic Gardens.

Maintenance, on a quarterly basis in the early years, included weeding, removal of spent flower heads and fertilising (Fig. 3). This maintenance took no more than one hour and is subsequently extended to twice a year, often annually in later years as the vegetation cover increases. Access for maintenance was not designed into either roof at ABG and this has made maintenance difficult. Staff require elevated access training and must be clipped onto the structure to safely maintain the roofs using ladders for access. A few stepping stones were installed in the middle of each roof to allow access for maintenance without compromising the health of the plants.

\section{Exotic roof}

The living roof over the Potter Children's Garden entrance was designed for maximum visual appeal in terms of colour and plant form. It was originally planted with blocks of large Echeveria elegans and Senecio serpens near edges; both species were chosen for their contrasting leaves. Clusters of Aloe humilis and A. aristata were interplanted with Neoregelia Night Sky' and other bromeliad hybrids at each end of the roof. E. elegans have generally grown better at the lower end of the roof and Aloe at the higher (and slightly drier) end. The hot flower colours were selected for early spring interest. The summerdormant bulb Ornithogalum dubium (South African sun star) was planted through Lampranthus species, which provided pink, yellow and red flowers and included L. aurantiacus (Fig. 4). The orange sun star flowers on 100 to $200 \mathrm{~mm}$ 


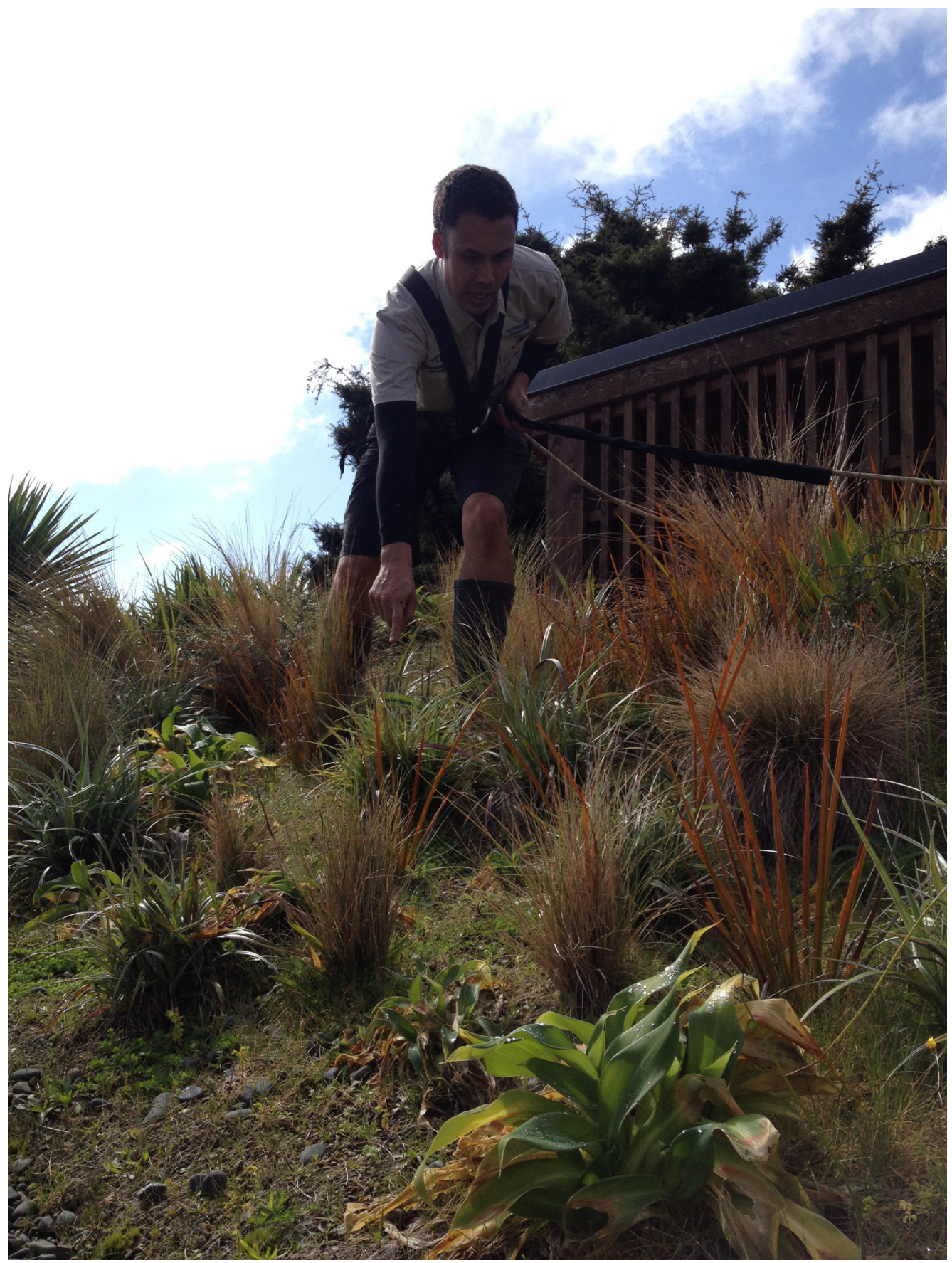

Fig. 3 Staff maintaining the roofs through weeding, removing spent flowers and fertilising. Photo: Emma Bodley.

spikes added interest to the roof in early summer. In 2011 clumps of Iris 'Magnolia' were planted. In 2012 more Neoregelia and other small (foliage $<200 \mathrm{~mm}$ high) bromeliad hybrids were interplanted along with Ruschia maxima, Tulbaghia violacea and low-growing Gazania and Sedum species. 


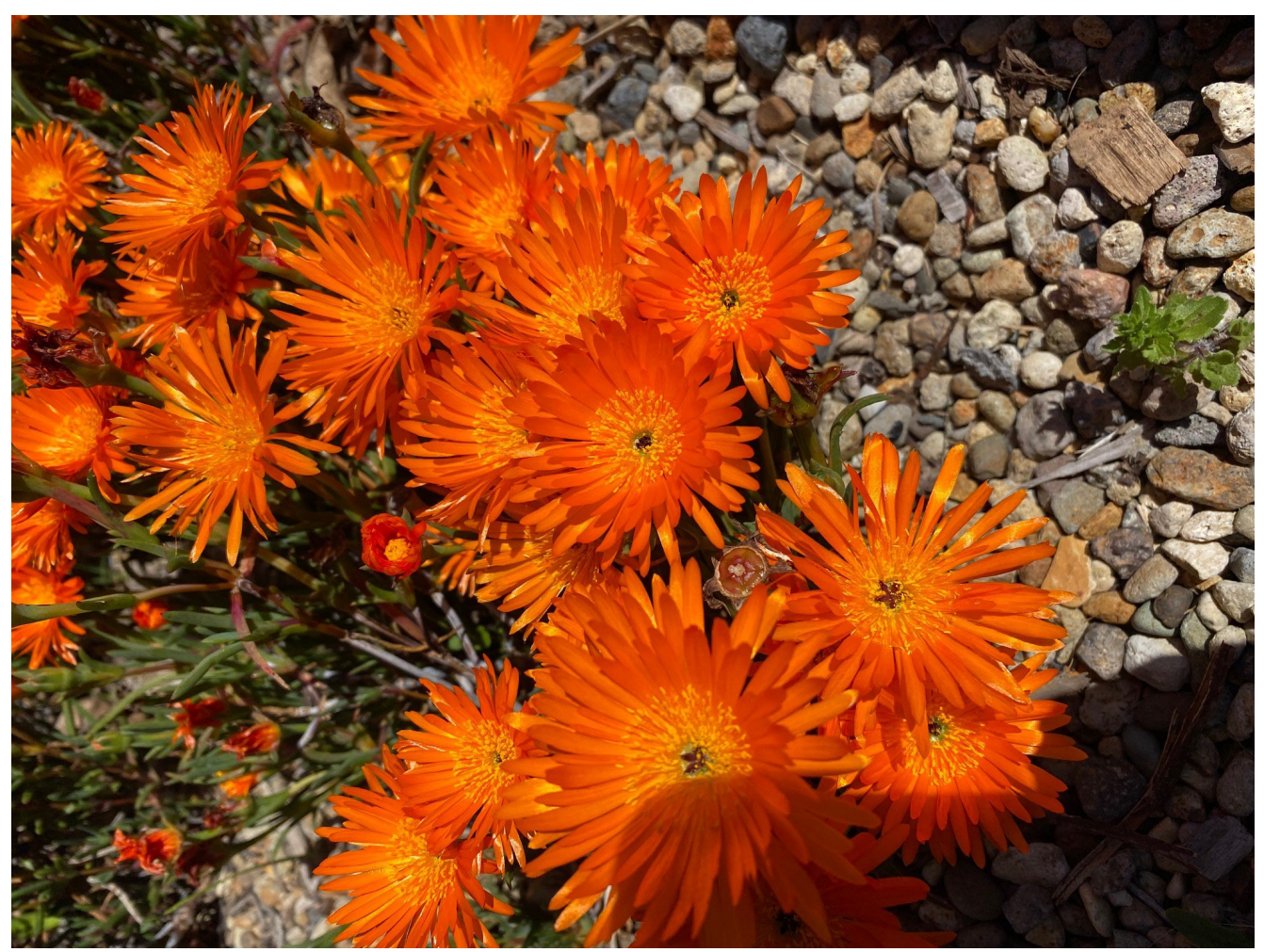

Fig. 4 Brilliant orange flowers of Lampranthus aurantiacus giving spring colour to the exotic living roof. Photo: Emma Bodley.

\section{Native roof}

The native living roof was planted predominantly with Muehlenbeckia complexa and Libertia peregrinans, with patches of native tussock grasses including Poa cita, Austrostipa stipoides and Chionochloa rubra, and small clumps of Coprosma acerosa 'Hawera' and Xeronema callistemon f. callistemon (Fig. 5). Spring 2011 growth on Muehlenbeckia was green but sparse. By August 2012 it was still not visually conspicuous and was not achieving the design intent of a green blanket wrapping over the roof, so Arthropodium cirratum (rengarenga), Leptospermum 'Wairere Falls' (Fig. 6), a prostrate manuka, Pimelea prostrata and Astelia banksii were planted and individual plants fertilised with slow-release fertilisers, either (13:5.7:10.8) at a rate of $30 \mathrm{~g} / \mathrm{m}^{2}$ or $120 \mathrm{~g} / \mathrm{m}^{2}$ sheep pellets (3 per

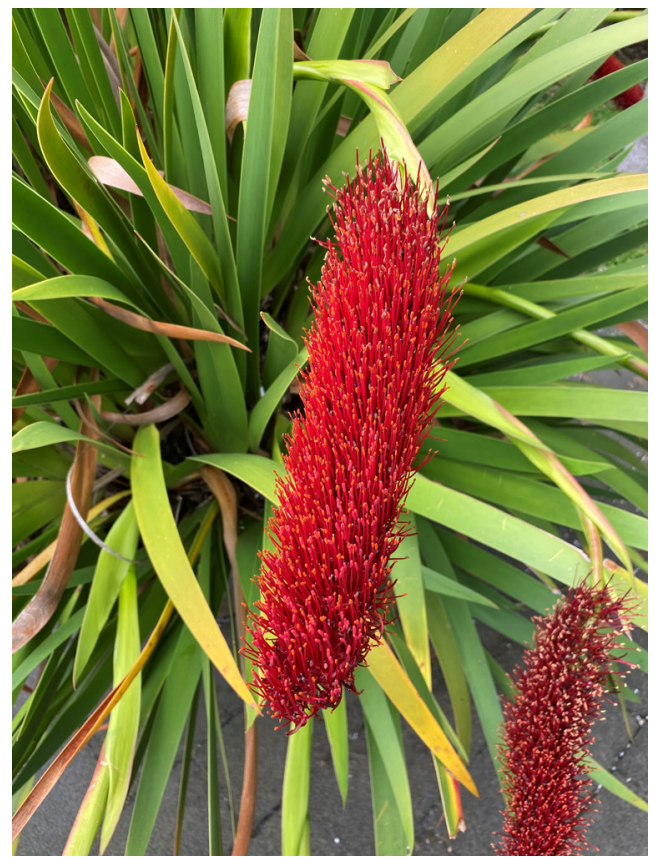

Fig. 5 Striking red flower of Xeronema callistemon $\mathrm{f}$. callistemon. Photo: Emma Bodley. 


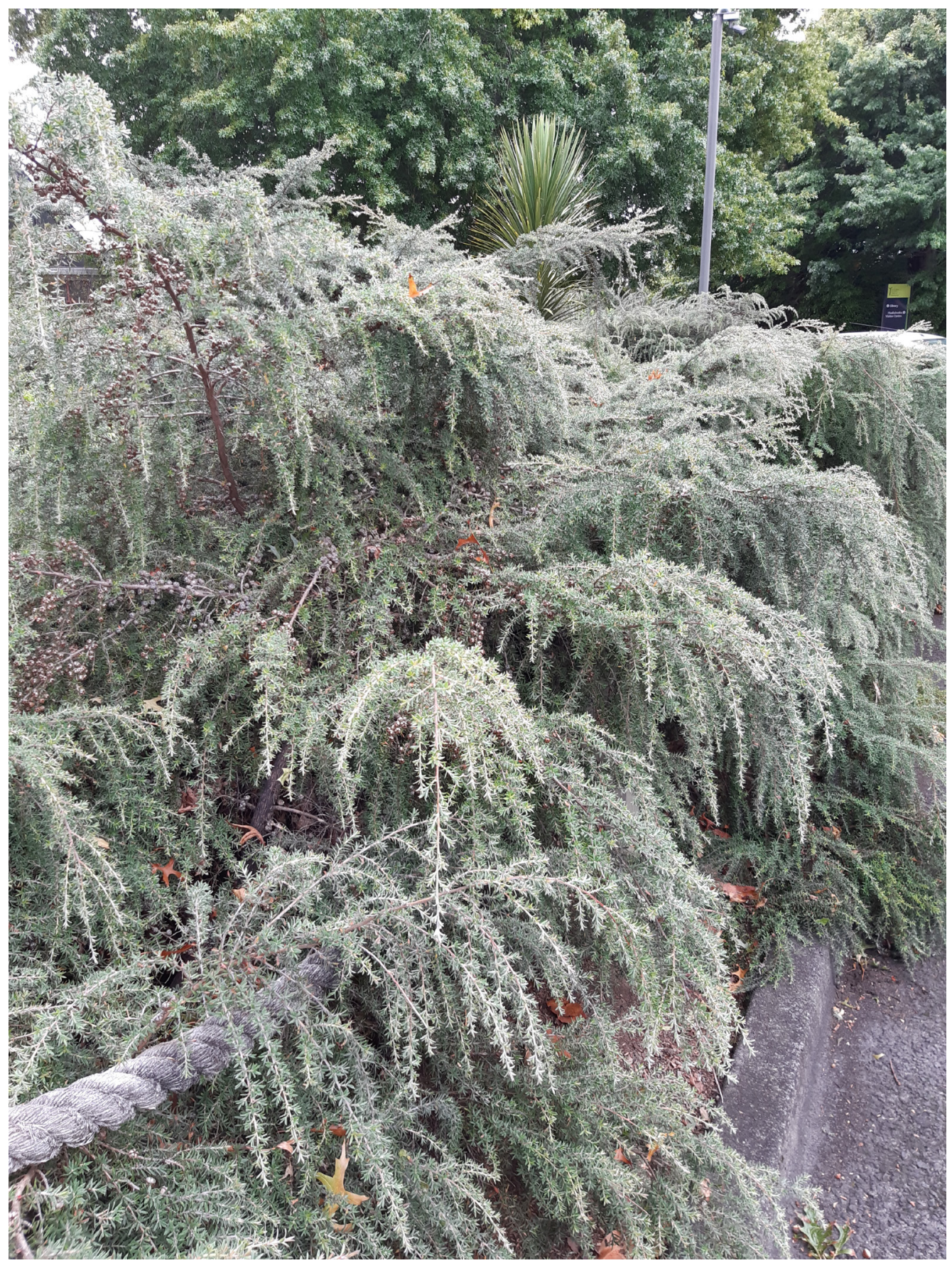

Fig. 6 Leptospermum 'Wairere Falls' with a prostrate, weeping habit. Photo: Emma Bodley.

cent N), to increase nitrogen supply to the plants. Fertilisers were placed below the surface in slits above targeted plants to avoid stimulating the weeds.

\section{Results}

Annual censuses, or plant stocktakes, of the roof have been conducted to capture information about the performance and 
surface cover of plants, as well as noting self-seeded plants. Self-seeded plants may be either native or exotic but have not been planted intentionally on the roofs. The current palette of plants on the native roof (Table 1) and exotic roof (Table 2 ) is presented here. A non-native plant in Table 1 is indicated by an asterisk $\left(^{*}\right)$. A record of plants that have been trialled and performed poorly can be found in Appendix 1.

Thirty plants have been recorded as self-seeding onto the living roofs at ABG, nine of which are New Zealand native plants. Metrosideros excelsa is a common wind-dispersed tree which has the ability to invade urban environments, growing in the slightest of substrates such as cracks in pavements, concrete walls and roof guttering. Its aggressive system of roots makes it highly undesirable on a living roof; Arthropodium cirratum is planted on the roofs and spreads by seed; Cordyline australis, Pseudopanax spp. (bird-dispersed trees) and Phormium tenax (a wind dispersed plant) are found plentifully at ABG. Pseudopanax lessonii (a very common bird-dispersed tree), Epilobium nummulariifolium and Pseudognaphalium luteoalbum (both wind-dispersed herbs) and the orchid Microtis unifolia are well-known spontaneously occurring native plants that have adapted well to both urban habitats and plant nurseries. Both E. nummulariifolium and M. unifolia could well have been present in the substrate when other plants were moved to the roof, though they are equally common in the garden setting for the same reason and could have dispersed to the roof from the garden. One self-arrival is a moss, which we believe to be native (Rosulabryum cf. subtomentosum).

The remainder of the self-seeded plants on the roof are exotic plants, the majority of which are common in $A B G$ and wind-dispersed; however some may also have been pot contaminants. This indicates the importance of acquiring plants from a supplier that places high importance on nursery biosecurity (Stanley \& Dymond, 2020) for planting on living roofs to avoid the need for weeding as much as possible.

\section{Exotic roof}

Several exotic plants have established well and remain on the exotic living roof; these have made it onto the recommended list (see Table 3). Others have either performed poorly or died out (Appendix 1). Several plants such as Lampranthus sp. have responded well to fertiliser. Sedum decumbens and S. rupestre have only survived in the gravel edges of the roof. Others, such as Iris 'Wanganui Gem', looked great but required deadheading which is difficult to do on a roof without regular access. Several plants were not identified to species level when the roof was planted in 2012. This was an oversight which will impede their promotion if they are proven to be successful as suitable roof plants. Some self-seeded plants were removed as seedlings which made identification problematic, and these are identified to genus level only.

\section{Native roof}

On the native roof, mortality was very low; however, the growth of all species was unacceptably slow, given the environment of a high-profile display garden with the requirement to establish cover quickly for stormwater function. The substrate was too low in nitrogen according to soil tests (C:N ratio $37,0.28$ per cent total $\mathrm{N}$ ), which was confirmed by observing the response of the plants to fertiliser application. Libertia spread slowly with its rhizomes, but the older leaves died back and new growth was stunted. 
Table 1 Observations of species on the native plant roof made in November 2020. A non-native plant is indicated by an asterisk (*).

\begin{tabular}{|c|c|c|}
\hline Name & Family & Year planted/Self-seeded \\
\hline Pseudopanax sp. (probably Pseudopanax lessonii) & Araliaceae & Self-seeded \\
\hline Arthropodium cirratum & Asparagaceae & 2012 \& Self-seeded \\
\hline Cordyline australis & Asparagaceae & Self-seeded \\
\hline Astelia banksii & Asteliaceae & 2012 \\
\hline Crepis capillaris* & Asteraceae & Self-seeded \\
\hline Erigeron karvinskianus* & Asteraceae & Self-seeded \\
\hline Erigeron sumatrensis* & Asteraceae & Self-seeded \\
\hline Hypochaeris radicata* & Asteraceae & Self-seeded \\
\hline Pseudognaphalium luteoalbum & Asteraceae & Self-seeded \\
\hline Senecio vulgaris* & Asteraceae & Self-seeded \\
\hline Sonchus oleraceus* & Asteraceae & Self-seeded \\
\hline Taraxacum officinale* & Asteraceae & Self-seeded \\
\hline Rosulabryum cf. subtomentosum & Bryaceae & Self-seeded \\
\hline Euphorbia peplus* & Euphorbiaceae & Self-seeded \\
\hline Lotus corniculatus* & Fabaceae & Self-seeded \\
\hline Medicago arabica* & Fabaceae & Self-seeded \\
\hline Trifolium repens* & Fabaceae & Self-seeded \\
\hline Libertia peregrinans & Iridaceae & 2010 \\
\hline Campylopus introflexus* & Leucobryaceae & Self-seeded \\
\hline Leptospermum 'Wairere Falls' & Myrtaceae & 2012 \\
\hline Metrosideros excelsa & Myrtaceae & Self-seeded \\
\hline Epilobium ciliatum* & Onagraceae & Self-seeded \\
\hline Epilobium nummulariifolium & Onagraceae & Self-seeded \\
\hline Microtis unifolia & Orchidaceae & Self-seeded \\
\hline Plantago lanceolata* & Plantaginaceae & Self-seeded \\
\hline Agrostis capillaris* & Poaceae & Self-seeded \\
\hline Austrostipa stipoides & Poaceae & 2010 \\
\hline Cortaderia sp.* & Poaceae & Self-seeded \\
\hline Elymus repens* & Poaceae & Self-seeded \\
\hline Poa annua* & Poaceae & Self-seeded \\
\hline Poa cita & Poaceae & 2010, self-seeded \\
\hline Rytidosperma racemosum* & Poaceae & Self-seeded \\
\hline
\end{tabular}




\begin{tabular}{|l|l|l|}
\hline \multicolumn{1}{|c|}{ Name } & \multicolumn{1}{c|}{ Family } & Year planted/Self-seeded \\
\hline Muehlenbeckia complexa & Polygonaceae & 2010 \\
\hline Prunus campanulata* $^{*}$ & Rosaceae & Self-seeded \\
\hline Coprosma acerosa 'Hawera' & Rubiaceae & 2012 \\
\hline Solanum nigrum* & Solanceae & Self-seeded \\
\hline Pimelea prostrata & Thymelaeaceae & 2012 \\
\hline Phormium tenax & Xanthorrhoeaceae & Self-seeded \\
\hline Xeronema callistemon f. callistemon & Xeronemataceae & $2010 ; 2013$ \\
\hline
\end{tabular}

Table 2 Observations of species on the exotic plant roof made in November 2020.

\begin{tabular}{|l|l|l|}
\hline \multicolumn{1}{|c|}{ Name } & Family & Year planted/Self-seeded \\
\hline Ruschia maxima & Aizoaceae & 2012 \\
\hline Aloe humilis & Aloeaceae & 2010 \\
\hline Aloe thompsoniae & Aloeaceae & 2017 \\
\hline Tulbaghia violacea & Amaryllidaceae & 2012 \\
\hline Tulbaghia violacea 'Silver Lace' & Amaryllidaceae & 2012 \\
\hline Cordyline australis & Asparagaceae & Self-seeded \\
\hline Ornithogalum dubium & Asparagaceae & 2010 \\
\hline Conyza albida/canadensis & Asteraceae & Self-seeded \\
\hline Gazania (various hybrids) & Asteraceae & 2012 \\
\hline Hypochaeris radicata & Asteraceae & Self-seeded \\
\hline Pseudognaphalium luteoalbum & Asteraceae & Self-seeded \\
\hline Senecio serpens & Asteraceae & 2017 \\
\hline Senecio vulgaris & Asteraceae & Self-seeded \\
\hline Sonchus oleraceus & Asteraceae & Self-seeded \\
\hline Taraxacum officinale & Asteraceae & Self-seeded \\
\hline Lampranthus aurantiacus & Azioaceae & 2010 \\
\hline Lampranthus sp. & Azioaceae & 2010 \\
\hline Neoregelia 'Night Sky' & Bromeliaceae & Self-seeded \\
\hline Echeveria sp. & Crassulaceae & 2010 \\
\hline Sedum decumbens & Crassulaceae & 2018 \\
\hline Sedum rupestre & Crassulaceae & 2018 \\
\hline Euphorbia peplus & Euphorbiaceae & Self-seeded \\
\hline Iris 'Magnolia' & Iridaceae & 2011 \\
\hline & & \\
\hline
\end{tabular}




\begin{tabular}{|l|l|l|}
\hline \multicolumn{1}{|c|}{ Name } & Family & Year planted/Self-seeded \\
\hline Iris 'Wanganui Gem' & Iridaceae & 2011 \\
\hline Epilobium ciliatum & Onagraceae & Self-seeded \\
\hline Microtis uniflora & Orchidaceae & Self-seeded \\
\hline Pinus sp. & Pinaceae & Self-seeded \\
\hline Plantago lanceolata & Plantaginaceae & Self-seeded \\
\hline Veronica persica & Plantaginaceae & Self-seeded \\
\hline Agrostis capillaris & Poaceae & Self-seeded \\
\hline Cortaderia sp. & Poaceae & Self-seeded \\
\hline Holcus lanatus & Poaceae & Self-seeded \\
\hline Paspalum dilatatum & Poaceae & Self-seeded \\
\hline Rytidosperma racemosum & Poaceae & Self-seeded \\
\hline Anagallis arvensis subsp. arvensis var. arvensis & Primulaceae & Self-seeded \\
\hline
\end{tabular}

Table 3 Top performing native and exotic plant species on living roofs in Auckland, New Zealand.

\begin{tabular}{|l|l|l|}
\hline \multicolumn{1}{|c|}{ Name } & \multicolumn{1}{c|}{ Family } & Native or exotic \\
\hline Disphyma australe & Azioaceae & Native (ground cover) \\
\hline Lampranthus sp. & Azioaceae & Exotic \\
\hline Ruschia maxima & Aizoaceae & Exotic \\
\hline Aloe humilis & Aloeaceae & Exotic \\
\hline Aloe thompsoniae & Aloeaceae & Exotic \\
\hline Tulbaghia violacea (including 'Silver Lace') & Amaryllidaceae & Exotic \\
\hline Arthropodium spp. (including A. cirratum) & Asparagaceae & Native \\
\hline Astelia banksii & Asteliaceae & Native \\
\hline Gazania sp. & Asteraceae & Exotic \\
\hline Leptinella spp. & Asteraceae & Native (ground cover) \\
\hline Senecio serpens & Asteraceae & Exotic \\
\hline Neoregelia sp. & Bromeliaceae & Exotic \\
\hline Carex 'raotest' & Cyperaceae & Native \\
\hline Carex pumila & Cyperaceae & Native \\
\hline Ficinia nodosa & Cyperaceae & Native \\
\hline Iris (including 'Magnolia' and 'Wanganui Gem') & Iridaceae & Exotic \\
\hline Libertia peregrinans & Iridaceae & Native \\
\hline Leptospermum 'Wairere Falls' (or prostrate forms) & Myrtaceae & Native (ground cover) \\
\hline
\end{tabular}




\begin{tabular}{|l|l|l|}
\hline \multicolumn{1}{|c|}{ Name } & \multicolumn{1}{c|}{ Family } & \multicolumn{1}{c|}{ Native or exotic } \\
\hline Austrostipa stipoides & Poaceae & Native \\
\hline Poa cita & Poaceae & Native \\
\hline Muehlenbeckia axillaris & Polygonaceae & Native (ground cover) \\
\hline Apodasmia similis & Restionaceae & Native \\
\hline Coprosma acerosa & Rubiaceae & Native (ground cover) \\
\hline Coprosma brunnea & Rubiaceae & Native (ground cover) \\
\hline Coprosma kirkii & Rubiaceae & Native (ground cover) \\
\hline Coprosma repens 'Poor Knights' (prostrate forms) & Rubiaceae & Native (ground cover) \\
\hline Leptostigma setulosa & Rubiaceae & Native (ground cover) \\
\hline Pimelea spp. including Pimelea prostrata & Thymelaeaceae & Native (ground cover) \\
\hline Xeronema callistemon f. callistemon & Xeronemataceae & Native \\
\hline
\end{tabular}

\section{Discussion and conclusions}

The recommended plants for roofs listed in Table 3 are those that have performed well in the trials at ABG. These roofs have supplemental irrigation in summer of 10 minutes twice a week from December to February and a substrate depth of $100 \mathrm{~mm}$. Increasing the depth of substrate to 200 $\mathrm{mm}$ and/or providing afternoon shade will broaden the range of species that are likely to be successful. This has been observed by the authors at Auckland Zoo.

In terms of non-native species, unlike thin living roofs in the UK or Northern Europe, we have found that most Sedum spp. trialled to date have not generally formed a dense or long-lived (more than five years) cover in the substrate (Hawke, 2015), unless they are on the edge in the drainage gravels where a few plants have managed to survive. This is consistent with research carried out on the University of Auckland School of Engineering trial roof and on Landcare Research roofs at Tamaki Campus, Auckland (Fassman et al., 2010a). However, Lampranthus and Tulbaghia have performed well. Standout non-native performers are bromeliads, and their success suggests that other species of epiphytes and lithophytes (widely used in South America) have great potential (Silva et al., 2018) although they are yet to be trialled at ABG. A consideration of mass planting of bromeliads needs to consider access for maintenance due to their spiky leaves. Other standout performers are summer-dormant bulbs such as Allium and Ornithogalum dubium. In Europe, A. schoenoprasum (chives) and Iris fulfil this role (Hawke, 2015). There is potential here for testing more bulb species that are good at spreading naturally on the roof, particularly bulbs that flower early in spring before drought conditions occur.

From our trials of a range of New Zealand native plants, we suggest they are planted on roofs that are at least $100 \mathrm{~mm}$ deep if irrigation is provided to allow establishment. Better results can be achieved with 150-250 mm of substrate or afternoon shade to allow for better soil water retention (Fassman-Beck \& Simcock, 2013; Simcock et al., n.d.), specifically in Auckland conditions. Further native species should be trialled to 
provide a greater palette of plants to enable the use of more New Zealand plants on living roofs. The best performing native plants to date include Arthropodium cirratum, Xeronema callistemon f. callistemon, Coprosma sp. and some sedges and grasses. There is probably a range of New Zealand woody plants that can persist in 100-200 mm deep substrate, including Coprosma and Pimelea. Root rot commonly affects species of Astelia and Xeronema, so we have kept them to the upper edge of the roof where the substrate is free draining and plants avoid the wetter zone.

There should be further investigation into using native epiphytes such as Astelia hastata based on our observations of epiphytic plants such as bromeliads performing well on the exotic living roofs. This requires some work into efficient propagation techniques as plants are not readily commercially available. There is potential for the shorter coastal flax species (Phormium tenax) and drought-resilient cultivars of oioi (Apodasmia similis), Ficinia nodosa, Dianella nigra, coastal grasses Chionochloa flavicans or C. rubra and Pachystegia insignis (Marlborough rock daisy) to be suited to living roofs and these should be considered in future trials as their natural habitats are similar to that of the conditions on a living roof (NZPCN, 2021).

First observations of tree seedlings arriving on the roofs were in 2012 and included Pinus sp., Prunus sp. (probably Prunus campanulata) and Pseudopanax sp. (probably P. lessonii). These have been removed repeatedly and none were found in census in November 2020. We have also seen native plants such as Metrosideros excelsa (pōhutukawa) arrive on the roof which we have treated as 'weedy' as they are unwanted on the living roof due to the mature size. However, they are likely to reinvade the roof and should be removed as soon as they are found in order to avoid structural damage.

It is important that all future roof plantings ensure that there are strategies employed to increase their resilience to drought so that plants do not require irrigation other than in severe and unusual drought, and not on a regular basis. This is particularly important at $A B G$ where sustainable horticultural practices promote little to no use of irrigation when ideal planting times are observed. Auckland also faced water restrictions from 2020 to 2021 where no irrigation was permitted due to water shortages. This is likely to be an ongoing challenge with climate change and varying rainfall in Auckland.

These strategies could include variation in depth of substrate (to create microclimates for different species), water retention devices such as pottery or wood, and varying plant heights where taller plants, such Arthropodium cirratum, create shade for less sun tolerant plants, such as Dichondra and Leptinella. Also selection of known drought tolerant plants such as Calamintha, Lavandula, Achillea and Thymus could be trialled as they do well in Auckland, and have performed well on living roofs elsewhere (Dunnett et al., 2011; Hawke, 2015; Seyedabadi et al., 2021).

We could consider using perennial species and more woody species, particularly for the exotic roof, listed in long term studies such as Lubell et al. (2017) and Schneider et al. (2021). Perennials that grow well in Auckland such as Solidago have not been trialled on the roofs due to the current theming on the exotic roof (Lubell et al., 2017), however careful consideration is required because perennials do not behave in the same way as they do in the northern hemisphere and require cutting back, therefore maintenance of plants is important in the Auckland context. 
There are still a lot of research possibilities to expand the palette of plants suitable for planting on living roofs in New Zealand, and ABG will carry this out over the next few years. We will continue to update our website with progress of these trials, as well as provide information to relevant council departments who develop guides and standards for living roofs. It would also be useful to consider the role plant selection can play to improve carbon sequestration (Seyedabadi et al., 2021) and reduce building footprints in dense urban settings. These lists will provide valuable information and experience which we hope developers and councils in New Zealand can use when designing and implementing new living roofs and redeveloping existing roofs.

\section{References}

AGRA, H., KLEIN, T., VASL, A., KADAS, G. \& BLAUSTEIN, L. (2021). Measuring the effect of plant-community composition on carbon fixation on green roofs. Urban Forestry and Urban Greening, 24: 1-4. doi: https://doi.org/10.1016/j.ufug.2017.03.003

AVERY, Z. \& DAVIES, R. (2019). Living roof guide: guide to living roofs, walls and facades in Whangarei, New Zealand. Available online: https:// www.wdc.govt.nz/files/assets/public/documents/ council/standards-guidelines/whangarei-livingroof-guide.pdf (accessed March 2021).

BRANDT, A.J., BELLINGHAM, P.J., DUNCAN, R.P., ETHERINGTON, T.R., FRIDLEY, J.D., HOWELL, C.J., HULME, P.E., JO, I., MCGLONE, M.S., RICHARDSON, S.J., SULLIVAN, J.J., WILLIAMS, P.A. \& PELTZER, D.A. (2021). Naturalised plants transform the composition and function of the New Zealand flora. Biological Invasions, 23(2): 351-366. doi: https://doi.org/10.1007/ s10530-020-02393-4

CUNNINGHAM, A., COLIBABA, A., HELLBERG, B., SILYN ROBERTS, G., SIMCOCK, R., SPEED, S., VIGAR, N. \& WOORTMAN, W. (2017). Stormwater management devices in the Auckland region. Auckland Council guideline document, GD2017/0001.

DUNNETT, N., GEDGE, D., LITTLE, J. \&

SNODGRASS, E. (2011). Small Green Roofs: Low-tech Options for Greener Living. Timber Press, Portland, OR.

DUNNETT, N. \& KINGSBURY, N. (2008). Planting Green Roofs and Living Walls (2nd edn). Timber Press, Portland, OR.

DVORAK, B. (2021). Ecoregional Green Roofs: Theory and Application in the Western USA and Canada. Springer International Publishing, Cham.

FASSMAN, E.A., SIMCOCK, R. \& VOYDE, E. (2010a). Extensive green (living) roofs for stormwater mitigation. Part 1: Design and Construction. Prepared by Auckland UniServices for Auckland Regional Council. Auckland Regional Council Technical Report 2010/017.

FASSMAN, E.A., SIMCOCK, R. \& VOYDE, E. (2010b). Extensive green (living) roofs for stormwater mitigation. Part 2: Performance Monitoring Appendix. Prepared by Auckland UniServices for Auckland Regional Council. Auckland Regional Council Technical Report 2010/018.

FASSMAN-BECK, E.A. \& SIMCOCK, R. (2013). Living roof review and design recommendations for stormwater management. Prepared by Auckland UniServices for Auckland Council. Auckland Council Technical Report TR2013/045.

GEDGE, D. \& LITTLE, J. (2008). The DIY Guide to Green and Living Roofs. Available online: https:// greenrooftraining.com (accessed March 2021).

GETTER, K. \& ROWE, D. (2006). The role of extensive green roofs in sustainable development. HortScience, 41(5): 1276-1285. doi: https://doi. org/10.21273/HORTSCl.41.5.1276

GUO, B., ARNDT, S., MILLER, R., LU, N. \&

FARRELL, C. (2021). Are succulence or trait combinations related to plant survival on hot and dry green roofs? Urban Forestry and Urban Greening, 64: 127248. doi: https://doi.org/10.1016/J. UFUG.2021.127248

HAWKE, R. (2015). An evaluation study of plants for use on green roofs. Chicago Botanic Garden, Plant Evaluation Notes, 38: 1-22.

HOPKINS, G. \& GOODWIN, C. (2011). Living Architecture: Green Roofs and Walls. CSIRO Publishing, Collingwood. 
HOWELL, C. (2008). Consolidated List of Environmental Weeds in New Zealand. Science \& Technical Publishing, Department of Conservation, Wellington.

IRGA, P.J., BRAUN, J.T., DOUGLAS, A.N.J., PETTIT, T., FUJIWARA, S., BURCHETT, M.D. \& TORPY, F.R. (2017). The distribution of green walls and green roofs throughout Australia: do policy instruments influence the frequency of projects? Urban Forestry and Urban Greening, 24: 164-174. doi: https://doi. org/10.1016/j.ufug.2017.03.026

KÖHLER, M. (2006). Long-term vegetation research on two extensive green roofs in Berlin. Journal of Urban Habitats, 4(1): 3-26.

KÖHLER, M. \& POLL, P. (2010). Long-term performance of selected old Berlin greenroofs in comparison to younger extensive greenroofs in Berlin. Ecological Engineering, 36(5): 722-729. doi: https://doi.org/10.1016/j.ecoleng.2009.12.019

LUBELL, J.D., CONNOLLY, B. \& JONES, K.N. (2017). Ten-year persistence of native plant species on a green roof in Northeast US. Native Plants Journal, 18(3): 227-234. doi: https://doi.org/10.3368/ npj.18.3.227

LUNDHOLM, J. (2006). Green roofs and facades: a habitat template approach. Urban Habitats, 4(1): 87-101.

MAGUIRE, K. \& WOODS, T. (2017). Big Ideas, Small Spaces: Creative Ideas and 30 Projects for Balconies, Roof Gardens, Windowsills, and Terraces. Mitchell Beazley, London.

NAGASE, A. \& TASHIRO-ISHII, Y. (2018). Habitat template approach for green roofs using a native rocky sea coast plant community in Japan. Journal of Environmental Management, 206: 255-265. doi: https://doi.org/10.1016/j.jenvman.2017.10.001

\section{NEW ZEALAND PLANT CONSERVATION} NETWORK (2021). Available online: www.nzpen. org.nz (accessed October 2021).

ROEHR, D. \& FASSMAN-BECK, E. (2015). Living Roofs in Integrated Urban Water Systems. Routledge, Abingdon.

SCHNEIDER, A., LANDIS, M. \& BOUSSELOT,

J. (2021). Observations on the survival capacity of 118 plant taxa on a green roof in a semi-arid climate: 12 year update. Journal of Living Architecture, 8(1): 19-40. doi: https://doi. org/10.46534/jliv.2021.08.01.019
SCHRIEKE, D. \& FARRELL, C. (2021). Trait-based green roof plant selection: water use and drought response of nine common spontaneous plants. Urban Forestry and Urban Greening, 65: 127368. doi: https://doi.org/10.1016/j.ufug.2021.127368

SEYEDABADI, M.-R., EICKER, U. \& KARIMI, S. (2021). Plant selection for green roofs and their impact on carbon sequestration and the building carbon footprint. Environmental Challenges, 4: 1-11. doi: https://doi.org/10.1016/j.envc.2021.100119 SILVA, B., MANTOVANI, A., MANTUANO, D., ROLA, S. \& BARBOSA, M. (2018). Evaluating plant species suitability for a substrate-free tropical green roof. OnLine Journal of Biological Sciences, 18(4): 401-423. doi: https://doi.org/10.3844/ ojbsci.2018.401.423

SIMCOCK, R., FASSMAN-BECK, E. \& ANSEN, J. (N.D.). Application of living (green) roof design recommendations for stormwater management. Available online: www.waternz.org.nz/Attachment ?Action=Download\&Attachment_id=731 (accessed March 2021).

SNODGRASS, E. \& MCINTYRE, L. (2010). The Green Roof Manual: A Professional Guide to Design, Installation and Maintenance. Timber Press, Portland, OR.

SNODGRASS, E. \& SNODGRASS, L. (2006). Green Roof Plants. Timber Press, Portland, OR.

STANLEY, R. \& DYMOND, W. (2020). Reducing risk to wild ecosystems in nursery production: the Nursery Biosecurity Project at Auckland Botanic Gardens, Aotearoa (New Zealand). Sibbaldia, 19: 59-68. doi: https://doi.org/10.24823/ Sibbaldia.2020.283

SUTTON, R. (2015). Green Roof Ecosystems. Springer International Publishing, Cham.

VOYDE, E., FASSMAN, E., SIMCOCK, R. \& WELLS, J. (2010). Quantifying evapotranspiration rates for New Zealand green roofs. Journal of Hydrologic Engineering, 15(6). doi: https://doi.org/10.1061/ (ASCE)HE.1943-5584.0000141

WEEDBUSTERS (2016). Plant Me Instead. Auckland Council.

WETHERMANN, C. (2007). Green Roof: A Case Study: Michael Van Valkenburgh Associates' Design for the Headquarters of the American Society of Landscape Architects. Princeton Architectural Press, New York. 


\section{Appendix 1}

List of plants, both native and exotic, that have been trialled on the living roofs at $A B G$ and have performed poorly, died or been outcompeted by other species on the roof.

\begin{tabular}{|l|l|l|}
\hline \multicolumn{1}{|c|}{ Name } & \multicolumn{1}{c|}{ Family } & Native or exotic \\
\hline Scandia rosifolia & Apiaceae & Native \\
\hline Astelia banksii & Asteliaceae & Native \\
\hline Echeveria splendens & Crassulaceae & Exotic \\
\hline Sedum 'Gold Mound' & Crassulaceae & Exotic \\
\hline Sedum palmeri & Crassulaceae & Exotic \\
\hline Sedum spectabile'Stardust' & Crassulaceae & Exotic \\
\hline Sedum spurium 'Voodoo' & Crassulaceae & Exotic \\
\hline Muehlenbeckia complexa & Polygonaceae & Native \\
\hline Acaena microphylla & Rosaceae & Native \\
\hline
\end{tabular}

